\title{
PLANT HUNTING THROUGH THE CENTURIES*
}

\author{
BY F. KINGDON WARD
}

$\mathrm{I}^{\mathrm{N}}$ I a sense, man has been searching for useful plants ever since he first appeared on the earth. Even in his hunting days before the end of the Ice Age he probably supplemented his diet with berries, seeds and roots. But for our present purpose we may ignore man before he became a cultivator, merely noting that even in those remote days he was a plant hunter.

We may perhaps picture primitive man slouching painfully across that early European landscape, haunted by the spectre of hunger, a child of sudden overwhelming impulse, fearful and bewildered, clutching, famished, at a handful of grass seeds or coloured berries, gnawing tough fruits, or chewing leaves. Through these bitter centuries he was learning gradually the first lesson man was compelled to learn in his dealings with the tremendous, infinitely old vegetable kingdom which he was destined one day to control : the difference between cellulose and starch or sugar, the difference, that is, between the structural materials of plants and the products they manufacture and set aside for future use; the cell wall and the cell contents. For cellulose is insoluble and therefore useless to man as food, since he cannot assimilate it; but sugar is soluble and starch is easily converted into sugar. Only the plant store-houses-fruits and seeds and certain usually underground parts and growing points-contain available food. The object of cultivation, besides being a matter of greater convenience, is to increase the soluble cell contents and eliminate as much as possible of the framework.

To get the botanical exploration of the world into perspective, it is necessary to go back eight or ten thousand years. The outline of the world was not then very different from what it is to-day. But there have been great changes in the mantle of vegetation since then, changes in the relative positions, and in the extent of forest, steppe and desert which are ultimately dependent on rainfall. It was vegetation, and hence climate, which determined not only which direction wandering man should take, but also where he should first begin to settle.

Although man must have been a hunter before he became a herdsman and a husbandman, through long ages all three must have existed together in different parts of the then habitable world. Man could have hunted only on the steppes; he could not have lived in the desert,

* Substance of a course of lectures delivered at the Royal Institution on January 16, 23 and 30. and in the forest he would have been a complete vegetarian. It would therefore be misleading to divide the time period into the three ages of hunting, herding and husbandry. Broadly speaking, herding suggests a nomadic, cultivation a settled, life. But there are many villages in Tibet to-day where no crops are grown, while in many parts of the world agriculture is itself nomadic. In densely forested regions the same patch of ground can only be cultivated at long intervals, and there comes a time when the village has to move. Abandoned village sites are common, for example, in far northern Burma.

Since we are dealing with a continuous evolution, no classification of the plant exploration period on a time basis can be other than arbitrary. Nevertheless, the following rough guide may be found convenient, though it involves a good deal of overlapping.

(a) The Search for Food Plants. Prehistoric period, from the beginnings of cultivation to the invention of writing, from about 7000 B.C. to about 4000 B.C.

(b) The Search for Economic Plants, other than staple foods, but including many food plants of secondary importance. Historic period, from 4000 B.C. to the discovery of the New World in A.D. 1492.

(c) The Search for Garden Plants. Modern period from A.D. 1492 to the present day.

This corresponds to some extent with three successive steps in the evolution of civilization, namely, (i) the search for economic plants, or as it is called to-day, raw material; (ii) the largescale cultivation in any convenient part of the world of economic plants ; and (iii) the large-scale manufacture of synthetic products from simple vegetable raw material. So we take up the story of plant hunting at the end of the pre-agricultural age ; the earliest plant hunters sought food plants.

Cultivation must have arisen independently in several centres; settlement was the basis of civilization. The primitive tribes of the eastern Himalayas, although new-comers (their chief crop is maize, which was unknown in Asia before the discovery of America) show traces of what early agriculture may have been. In the vicinity of Abor and other villages, fruit trees such as Artocarpus, peach, cherry, Citrus, quince, are much commoner than elsewhere, showing how settled people eat the fruits and spit out the seeds, which germinate in the village clearing. 
In the Mishmi Hills, the medicinal herb Coptis Teeta grows in the forest, above the highest cultivation. The natives clear the ground, cut down a few trees, and encourage the Coptis by stifling opposition. These tribes also show how from very early times man has used vegetation in its raw state, as timber, etc. The use of bamboos for water-tubs, lianas for ropes, or the fibrous bases of palm leaves for cloaks are examples. The first thing man ever made for himself was a wooden (cellulose) club. One of the latest things he has provided himself with on a vast scale is also made of cellulose-nitro-cellulose, the basis of many high explosives.

The natural distribution of plants over the earth has until recently been a decisively limiting factor in man's economy. Until the exploration of the world was far advanced, the people of Malaya had no chance of cultivating Brazilian rubber, nor the people of Brazil of cultivating Arabian coffee. Nor were these substances required in bulk. Not only are the plants of different parts of the world different, even for the same climate, but also they are of unequal value. Nowadays this unevenness of distribution can be levelled up by transporting any plant from where it grows naturally to any part of the world where it will grow. Plants regarded as of less importance are swept away to make room for huge crops of one kind, such as rubber, quinine, sugar cane or tung oil. The vegetation of the earth is everywhere being rapidly altered by man.

It has been shown by de Candolle, and more recently by Vavilov and others, and endorsed by antiquarians, that the earliest civilizations began in those regions whence most of our oldest cultivated crops have been derived. But nowadays the great centres of civilization bear no relation to, or are quite independent of, the original homes of the cultivated crops. That is a very significant fact.

After food, man's chief need was clothing. When animal skins became rarer, he turned to cellulose, and wore leaves. To-day most of the world's clothing is made of cellulose products such as cotton and rayon. The art of weaving is older than that of writing.

In the Ancient World new ideas diffused slowly, but they were quickened later as the result of pilgrimages, campaigns like that of Alexander, and trading. When civilization was disintegrating all over the world between A.D. 1050 and A.D. 1250 , owing to the attacks of barbarians, cellulose came to the rescue with the increasing use of paper, which made books possible. Knowledge was preserved without accumulating error, and degenerating into legend. The earliest paperpapyrus (pith), Aralia japonica (pith), and palm leaf-was practically pure cellulose and useless for books. But the invention of paper which would take print was a fundamental step in the forward march of civilization. Printing itself was of less importance than paper; it increased the speed of diffusion, without any corresponding increase of accuracy, so that myths were as readily propagated as truth ; for example, in modern times the widely believed story of mummy wheat germinating.

From the beginning, agriculture has had a disastrous effect on the natural cover of vegetation, and one of ever-increasing severity, especially in areas of natural grassland and in mountainous forested country where shifting cultivation is practised. The plough has proved one of the most destructive weapons ever put into the hands of man. Within the last few centuries pastoral man has become almost as destructive as agricultural man, as a result of cutting down forest to increase the area of pasture. The damage is clearly seen in many parts of the eastern Himalayas, where the local climate is being altered, and much land becoming derelict.

Two hundred years after Marco Polo's journey, the overland route through Eurasia was virtually closed. Diaz then rounded the Cape, and Columbus discovered the New World. As a result, the age of maritime exploration began, and more was learnt of tropical than of any other type of vegetation. The coasts and the estuaries of great rivers were explored. But for lack of roads, the interiors of the continents remained hidden, and it was not until the nineteenth and twentieth centuries, and the intensive search for gold, that the building of roads and railways made inland exploration possible. The historic voyages of the seventeenth and eighteenth centuries did nothing to make known the vegetation of the interiors of continents. The interior of Africa, of Australia, of Central Asia and of South America have been known to scientific men for little more than a century; the interior of Tibet, and of New Guinea, for less than fifty years. Now that transport problems have been solved, new obstacles in the form of 'national interests' are making scientific exploration over considerable portions of the least-known parts of the world increasingly difficult.

After food and fibre plants, man sought dyes, drugs, soap, scents and such-like things. While searching for food plants he may have discovered soothing or uplifting properties by chance, for example, opium poppy seeds, which the Mishmis eat, tobacco, hemp. Fermentation of his stored grain taught him the use of alcohol. In modern times, oil-producing fruits and seeds are in great demand. The plantation industry grew up with the Mechanical Revolution; raw material was needed to feed the machines. When the topography of the world had been mapped, the mapping of the 
vegetation and of the rocks followed. From the beginning, unusual looking plants attracted man's attention; and it was but a short step to cultivate flowers. With the advance of civilization, horticulture took a prominent place. In spite of the intensive exploration of the world for new plants during the last 1,500 years, not one unknown economic plant of any importance has been newly discovered. Even tung oil and soya bean, than which few plants have come into greater prominence recently, were cultivated several thousand years ago. On the other hand, many beautiful garden plants have been newly discovered.

Apart from horticulture, perhaps five hundred species of plants are now cultivated on a commercial scale-a very small proportion of the total known flora. The tendency is to reduce rather than increase the number, as the chemist learns how to synthesize plant products. Thus coal tar dyes supersede vegetable dyes, although coal tar is itself, ultimately, derived from vegetation ; and better varieties of wheat drive out inferior varieties. The increasing cultivation of herbs for the herb drug market perhaps restores the balance.

Apart from the staple cereal and fibre plants, and the various sources of such things as cellulose and timber, the most important economic crops to-day are : rubber, soya bean, quinine, tea, coffee, cocoa, sugar cane, banana, tung oil, varnish tree (Rhus), tobacco, opium, sisal and jute. The chief supply of nearly every one of these is now far from its original source, often in a different continent, as coffee, rubber, quinine and sisal. This has been brought about at the expense of the original vegetation, as a direct result of the growing economic interdependence of mankind. But it only became possible when the main features of the world's vegetation were known. It is obviously an advantage that all men who want tea or soap should be able to obtain these things, rather than that they should be confined to the few ; but mankind is going through a period of intense economic readjustment in order to achieve this desirable end of plenty of everything for all. There is a further conflict between what men need at any given level of civilization, and what 'interests' can persuade them to want.

The world is far from being botanically explored yet. But much of what remains to be done is predictable, thanks to increased knowledge. This enables us to carry on the work more systematically. There may not seem to be the same careless rapture in exploring a given region for largely predictable plants that there might be in wandering through unexplored worlds. But lack of knowledge is a real handicap. It is because we see the past world through eyes which have been opened that it looks romantic. To contemporary man the vegetation must have been confusing, exasperating and overwhelming. So far as plant exploration is concerned, the present is the age of the intensive specialized botanical explorer and the chemist.

\section{PRESERVATION OF GEOLOGICAL RECORDS*}

\section{By Dr. M. MACGREGOR, \\ Geological Survey of Great Britain}

$\mathrm{T}$ HE preservation in a carefully documented and permanent form of geological records of all kinds is a matter which should be regarded as of the utmost importance, and the opportunity is taken here of stressing the need for conjoint action to deal with it. If the examples used by way of illustration are drawn entirely from Scottish sources, it is partly because they have come directly under my own observation and partly because the suggestions advanced may gain in cogency if their application to one particular region is emphasized.

The importance of preserving geological sections of outstanding.or critical significance has long been récognized. These may be conveniently grouped into three broad, more or less arbitrary, categories.

- Substance of an address prepared for the Conference of Delegate of Corresponding Societies at the Dundee meeting of the British Association.
They may, for example, illustrate unique episodes in the history of the earth ; they may represent landmarks in the progress of geological thought or symbolize striking advances in our knowledge of geological processes ; they may, again, be sections that require re-examination and re-consideration from time to time in the light of modern research. For these and other reasons-historical, educational and scientific-the question of their preservation is a challenging one for all geologists.

These three categories may be very briefly dealt with. It would not be easy to select a more impressive illustration of the first of them than the little trial quarry at the roadside $3 \frac{1}{2}$ miles north-west of Inchnadamph, in Sutherlandshire (Geol. Surv. Photo. C. 2019). Here the basal beds of the Torridon Sandstone, containing windfacetted pebbles, rest discordantly upon an 